\title{
Glass-ceramic produced with recycled glass
}

\author{
Enzo Hanning ${ }^{1}$, Hiasmim Rohem Gualberto ${ }^{1}$, Karla Mayara Arguelles Simões ${ }^{2}$, \\ Luis Carlos Bertolino ${ }^{3}$, Edgard Poiate ${ }^{1}$, Mônica Calixto Andrade ${ }^{1}$,
}

\footnotetext{
${ }^{1}$ Instituto Politécnico - IPRJ/UERJ, CEP: 28625-570, Nova Friburgo, Rio de Janeiro, Brasil.

${ }^{2}$ Instituto de Química - IQ/COPPE/UFRJ, CEP: 21941-909, Rio de Janeiro, Rio de Janeiro, Brasil.

${ }^{3}$ Technology Characterization Sector - SCT/CETEM, CEP: 21941-908, Rio de Janeiro, Rio de Janeiro, Brasil. e-mail: enzohanning@gmail.com, hiasmimrohem@gmail.com, poiate@yahoo.com.br, monicacalixtoandrade@gmail.com, karla.carestiato@gmail.com, lcbertolino@cetem.gov.br
}

\begin{abstract}
The objective of this work is the production and characterization of glass-ceramic with recycled glass powder and $4 \%(\mathrm{w} / \mathrm{w})$ of cerium dioxide. Eleven groups were defined with conformation pressure of 11.6 and 25.8 $\mathrm{MPa}$, and cerium dioxide addition. The sintering temperatures of $650,675,700$ and $750{ }^{\circ} \mathrm{C}$ were used. The raw material was formed into a mold with a uniaxial pressure. The density was measured by the Archimedes principle. The water absorption of the groups was also determined, as linear contraction percentage and the crystalline structure. The flexural strength was obtained by the three-point bending test and the results analyzed by the Weibull analysis. The specimens presented density ranging from 1.99 to $2.38 \mathrm{~g} / \mathrm{cm} 3$. Increasing the temperature provided an increase in the density of the specimens and the flexural strength. At higher sintering temperature, this behavior was not observed. The highest flexural strength was $63.55 \mathrm{MPa}$, obtained at the sintering temperature of $700{ }^{\circ} \mathrm{C}$, conformed with $25.8 \mathrm{MPa}$, only glass powder. The increase in the forming pressure favored crystallization. The addition of cerium dioxide favored for the increase density and the Weibull modulus, but decrease of the flexural strength.
\end{abstract}

Keywords: Glass-ceramic, Flexural Test, Weibull Analysis, Wasted Glass recycling and Cerium Dioxide.

\section{INTRODUCTION}

The production of glass powder or amorphous materials is expensive because it requires high temperatures to reach the melting point of the industrial mineral blend [1] or sophisticated techniques for the synthesis of amorphous material. This has aroused interest in the use of already molten material, that is, already amorphous, such as recycled glass powder and other types of tailings [3-6].

On the other hand, "glass-ceramic" has a high potential for application, with excellent thermal, mechanical, chemical, biological and dielectric properties, becoming a target of great technological interest [7-8]. The process of glass powder recycling is based on the theory of glass-ceramic transformation by the nucleation and growth of crystals in its glass matrix [9].

Numerous studies show the importance of glass-ceramic. They are smooth materials, have higher flexural strength than glass and, in relation to ceramic materials, have better mechanical properties due to lower residual pore contents, which can provide the machinability of the glass ceramics. They may have low electrical conductivity and thermal dilation close to zero $[6,10]$. These properties may even be improved with the addition of oxides to the glass. Cerium oxide is an example, it is a nucleating agent used to improve sintering, strength and thermal stability of the glass-ceramics [11].

This research studied the production of glass ceramics with recycled glass powder of white ampoule, using cerium dioxide as a nucleating agent, and low sintering temperatures. The use of glass powder from recycled white ampoules will decrease the cost for material production, eliminating the melting stage, such as the consumption of new industrial minerals. The mechanical properties of the glass-ceramics were evaluated by increasing the sintering temperature, increasing the forming pressure and adding the cerium oxide in the glass powder. 


\section{MATERIALS AND METHODS}

To produce glass powder, white or broken glass ampoules were grinded by company Minasolo (São Paulo, Brazil). Table 1 shows the physical and chemical characteristics of the glass powder reported by Minasolo.

For each specimen, $10 \%$ weight/weight of water in glass powder and $4 \%$ weight/weight cerium dioxide were used in some conditions $\left(\mathrm{CeO}_{2}\right)$. The specimens were uniaxially formed, for $60 \mathrm{~s}$, in a steel, metal mold, $28.31 \mathrm{~mm}$ length and $7.30 \mathrm{~mm}$ width. Each group produced contained 15 specimens under the same experimental conditions. The shaped specimens were submitted to a drying process, being kept at $110{ }^{\circ} \mathrm{C}$ for one hour. So, they were sintered in air for one hour at the temperatures of 650,700 and $750{ }^{\circ} \mathrm{C}$, with a heating rate of $5{ }^{\circ} \mathrm{C} / \mathrm{min}$. Additionally, the sintering temperature of $675^{\circ} \mathrm{C}$ was adopted for the highest pressure since the specimens produced at this pressure showed the best properties. Table 2 shows the experimental conditions of the produced glass-ceramic specimens.

Table 1: Physical chemical characteristics of glass powder.

\begin{tabular}{l|l}
\hline $\mathrm{SiO}_{2}$ & $80.53 \%$ \\
\hline $\mathrm{Al}_{2} \mathrm{O}_{3}$ & $3.64 \%$ \\
\hline $\mathrm{Fe}_{2} \mathrm{O}_{3}$ & $0.08 \%$ \\
\hline $\mathrm{Na}_{2} \mathrm{O}$ & $7.96 \%$ \\
\hline $\mathrm{K}_{2} \mathrm{O}$ & $0.05 \%$ \\
\hline $\mathrm{BaO}$ & $1.37 \%$ \\
\hline $\mathrm{MgO}$ & $0.05 \%$ \\
\hline $\mathrm{CaO}$ & $0.49 \%$ \\
\hline $\mathrm{TiO}$ & \\
\hline $\mathrm{PbO}$ & $0.09 \%$ \\
\hline $\mathrm{B} \mathrm{O}_{3}$ & $0.02 \%$ \\
\hline Loss to fire & $5.38 \%$ \\
\hline Melting point & $0.39 \%$ \\
\hline & $850{ }^{\circ} \mathrm{C}$ \\
\hline
\end{tabular}

Table 2: Experimental conditions of glass ceramics.

\begin{tabular}{|c|c|c|c|}
\hline GROUP & COMPOSITION & $\begin{array}{l}\text { CONFORMATION } \\
\text { PRESSURE (MPa) }\end{array}$ & $\begin{array}{l}\text { TEMPERATURE } \\
\left({ }^{\circ} \mathrm{C}\right)\end{array}$ \\
\hline G1 & \multirow{7}{*}{ Glass powder } & \multirow{3}{*}{$11.6(\mathrm{C} 1)$} & 650 \\
\hline G2 & & & 700 \\
\hline G3 & & & 750 \\
\hline G4 & & \multirow{4}{*}{$25.8(\mathrm{C} 2)$} & 650 \\
\hline G5 & & & 675 \\
\hline G6 & & & 700 \\
\hline G7 & & & 750 \\
\hline G8 & \multirow{4}{*}{$\begin{array}{l}\text { Glass powder }+ \\
\mathrm{CeO}_{2}\end{array}$} & \multirow{4}{*}{$25.8(\mathrm{C} 3)$} & 650 \\
\hline G9 & & & 675 \\
\hline G10 & & & 700 \\
\hline G11 & & & 750 \\
\hline
\end{tabular}

The chemical composition of the glass powder was determined by fluorescence X-ray spectrometry. This analysis was carried out in the Laboratory of Combinatorial Catalysis (LACCO/DCAP), of the National Institute of Technology (INT, Brazil) in the equipment X-ray Fluorescence Spectrometer, model S8 Tiger (Bruker, Germany). The particle size analysis was performed in the glass powder before the production of the specimens, in the Mastersizer 2000, Hydro 2000MU (Malvern Instruments Ltd, England).

Fifteen measurements of the granulometric distribution were performed. The first three were performed without ultrasonic waves, only with shaking of the glass powder in the water. Ultrasonic waves were then used for one minute and three measurements were taken. This was done until the distribution remained 
constant. The result was appeared only after the fifteenth measurement.

The Archimedes method was used to measure the apparent density (AD) in seven specimens from each group. The dry mass was performed after $8 \mathrm{~h}$ at $110^{\circ} \mathrm{C}$. The moist and immersed masses were measured after $24 \mathrm{~h}$ of boiling ( $2 \mathrm{~h}$ boiling) and kept immersed in water. The apparent density is calculated from the equation (1).

$$
A D=\left(\frac{D M}{W M-I M}\right) * \rho_{\text {water }}
$$

Where the specific mass of the water $\left(\rho_{\text {water }}\right)$ is equivalent to $1 \mathrm{~g} / \mathrm{cm}^{3}$, at the room temperature of 25 ${ }^{\circ} \mathrm{C}$, DM is the dry mass, WM in the wet mass and IM is the immerse mass. The percentage of water absorption (WA) is calculated according to equation (2).

$$
W A=\left(\frac{W M-D M}{D M}\right) * 100 \%
$$

The linear contraction percentage in width and length were obtained through equation (3), where, $\mathrm{L}_{\mathrm{i}}$ and $\mathrm{L}_{\mathrm{f}}$ initial distance before burning and after burning, respectively.

$$
\mathrm{LR}=\left(\frac{\mathrm{L}_{\mathrm{i}}-\mathrm{L}_{\mathrm{f}}}{\mathrm{L}_{\mathrm{i}}}\right) 100 \%
$$

A three-point bending test was performed according to ASTM C1161-13 [12], in specimens with a nominal rectangular cross section around $7.00 \times 2.50 \mathrm{~mm}$ with loading rate of $0.2 \mathrm{~mm} / \mathrm{min}$ in a AG-X Plus Universal Machine Test (Shimadzu, Japan). Relative humidity was $60 \%$ and room temperature of the test was $20.6{ }^{\circ} \mathrm{C}$. The free space used was $20 \mathrm{~mm}$ and the load cell was $100 \mathrm{kN}$. The test was specified and data record in a Trapezium software (Shimadzu, Japan). From the rupture force $(F)$ and measured specimen dimensions (measured three times) length $(L)$ width $(b)$ and thickness $(h)$ was evaluated the rupture stress $\left(\sigma_{\mathrm{f}}\right)$ by equation (4) [12].

$$
\sigma_{f}=\frac{3 * F * L}{2 * b * h^{2}}
$$

Weibull analysis was applied in the flexural strength results [13].

The apparent density, water absorption, linear contraction, and flexural strength results were analyzed by one-way ANOVA and Tukey's test at the $5 \%$ significance level in a WINKS 4.80a software (Texsoft, EUA).

A sintered part of each group was ground and the X-ray diffraction (XRD) analysis was performed on the Bruker-D8 Endeavor diffractometer (Bruker, Germany) with copper tube, CuKa (40 kV/40 mA). The

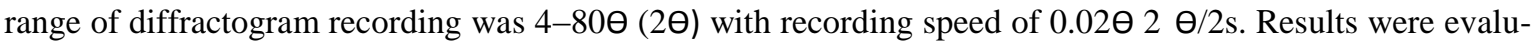
ated with XRD patterns, contained in the database PDF02 (ICDD, 2006) in a Bruker DiffracPlus software (Bruker, Germany).

\section{RESULTS AND DISCUSSIONS}

Table 3 shows the composition determined by X-ray fluorescence. Comparing these results with those of the supplier (Table 1) it was possible to observe a difference in the chemical composition percentage. This difference may be due to the detection limit of the X-ray fluorescence spectrometer used in this work, which did not detect other elements indicated by the supplier. But the important thing to note is that the main component in the glass powder used is silicon oxide, followed by sodium and aluminum oxide. All are very inert and stable compounds. Also, with this analysis we can observe that the glass powder used in this project has a similar composition to the raw material used for the glass ceramics production [6], that are of higher cost $[14,15]$. 
Table 3: Chemical composition determined by X-ray fluorescence spectroscopy.

\begin{tabular}{l|l}
\hline COMPOSITION & PERCENTAGE (\%) \\
\hline $\mathrm{SiO}_{2}$ & 87.40 \\
\hline $\mathrm{Na}_{2} \mathrm{O}$ & 6.16 \\
\hline $\mathrm{Al}_{2} \mathrm{O}_{3}$ & 4.86 \\
\hline $\mathrm{CaO}$ & 1.57 \\
\hline
\end{tabular}

Figure 1 shows the granulometric distribution of the glass powder used in this work for making the specimens. It is observed that the distribution is monomodal and its d 50 was $30.049 \mu \mathrm{m}$, which means that $50 \%$ of the particles have a size up to $30.049 \mu \mathrm{m}$. In addition, there is a wide distribution, according to the scale proposed by Merkus (2009). Thus, there is a wide range of particle sizes, which favors the packaging of the particles and the densification of the material $[16,17]$.

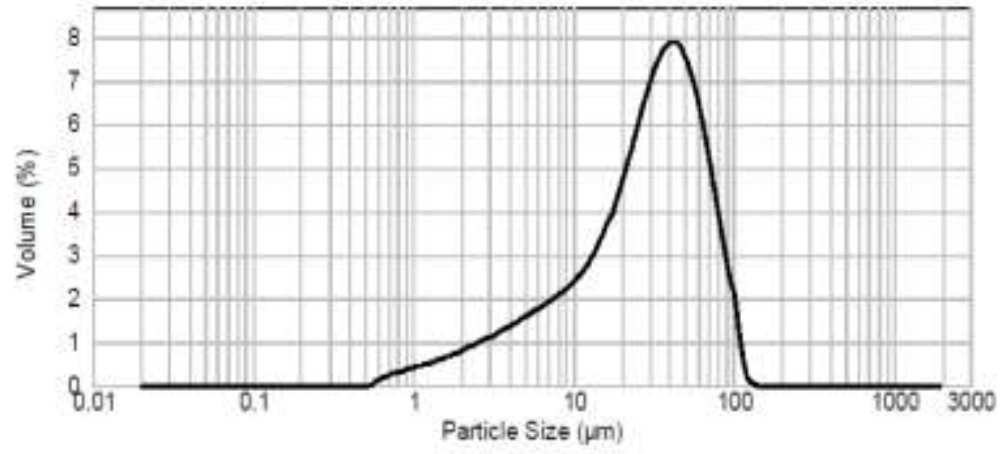

Figure 1: Granulometric distribution of the glass powder.

It was observed in Table 4 and Figure 2 that in all compositions and conformational pressures, the bulk density (AD) increased with increasing sintering temperature, except for 700 to $750{ }^{\circ} \mathrm{C}$. The increase in temperature reduces the viscosity of the flow, facilitating sintering and densification. However, from $700{ }^{\circ} \mathrm{C}$, it is noticed that the increase in temperature does not favor the densification of the specimens. This is due to the increased viscosity of the flow. When crystallization occurs before the sintering is complete, there is an in-crease in flow viscosity, impairing densification $[18,19]$. Residual porosity, which is a viscous flow sintering problem, is also due to the release of dissolved gas and / or insoluble gases entrapped in the initial pores [18].

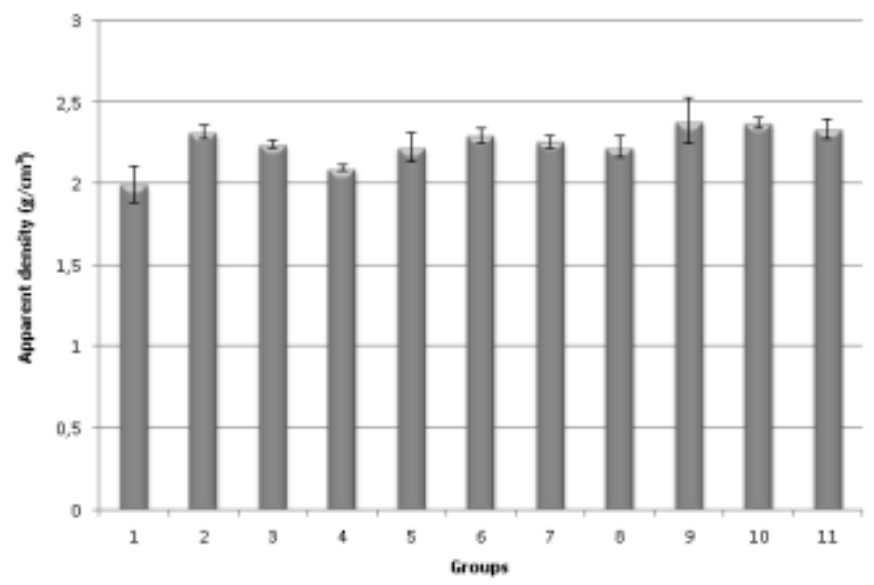

Figure 2: Apparent density data. 
Table 4: Average apparent density and percentage of water absorption in the sintered specimens.

\begin{tabular}{l|l|l|l|l}
\hline & \multicolumn{2}{|l|}{$\begin{array}{l}\text { APPARENT DENSITY } \\
\left(\mathrm{g} / \mathrm{cm}^{3}\right)\end{array}$} & \multicolumn{2}{l}{$\begin{array}{l}\text { WATER ABSORPTION } \\
(\%)\end{array}$} \\
\hline & mean & SD & mean & SD \\
\hline G1 & 1.99 & 0.22 & 9.17 & 2.62 \\
\hline G2 & 2.31 & 0.08 & 0.24 & 0.10 \\
\hline G3 & 2.24 & 0.05 & 0.20 & 0.06 \\
\hline G4 & 2.09 & 0.04 & 4.36 & 1.14 \\
\hline G5 & 2.22 & 0.18 & 1.52 & 0.80 \\
\hline G6 & 2.29 & 0.09 & 0.58 & 0.34 \\
\hline G7 & 2.25 & 0.07 & 0.20 & 0.08 \\
\hline G8 & 2.22 & 0.13 & 4.74 & 1.89 \\
\hline G9 & 2.38 & 0.28 & 1.39 & 1.10 \\
\hline G10 & 2.37 & 0.07 & 0.55 & 0.18 \\
\hline G11 & 2.33 & 0.12 & 0.17 & 0.10
\end{tabular}

It can also be observed in the Figure 2 that there has been an increase in the AD with the increase of the conformation pressure and with adding cerium dioxide in the specimens. These results are confirmed by the decrease in the percentage of water absorbed (WA) by the specimens, with the increase of the sintering temperature. A significant absorption of water at low sintering temperatures is observed in Table 4, however, after the increase in $50{ }^{\circ} \mathrm{C}$, the percentage of water absorption drops drastically, being constant, without further reduction until reaching the temperature of $750{ }^{\circ} \mathrm{C}$, in which there is a small reduction of density. Despite this, in this temperature there is no increase in water ab-sorption, as there is greater crystallization and vitrification on the surface at high temperatures, which makes it difficult to absorb water, even if the part is porous internally. Although, in $750{ }^{\circ} \mathrm{C}$, the density decreases there is no increase in water absorption. According to Zhang et al. (2013) higher sintering temperatures promote surface densification [20]. Due to high temperatures, the vis-cous flow resistance of the glass is smaller on the surface than on the inside of the part. Thus, in the higher temperatures, the specimens densified better superficially, resulting in a lower water absorption.

As can be observed in Figure 3, the highest water absorption and the highest standard deviation (SD) occurred in groups G1, G4 and G8, those associated with lower sintering temperatures. This exaggerated absorption reveals that the sintering process was not efficient, producing a porous material. The increase in the pressure of conformation of the test specimens favors the compaction. This justifies the lower water absorption in the sintered samples at the temperature of $650{ }^{\circ} \mathrm{C}$, when the forming pressure increases. The percentage of water absorption in the samples decreased when the cerium dioxide was added and the set pressure increased, facts related to the better compaction and the higher crystallization and surface vitrification provided by the nucleante agent.

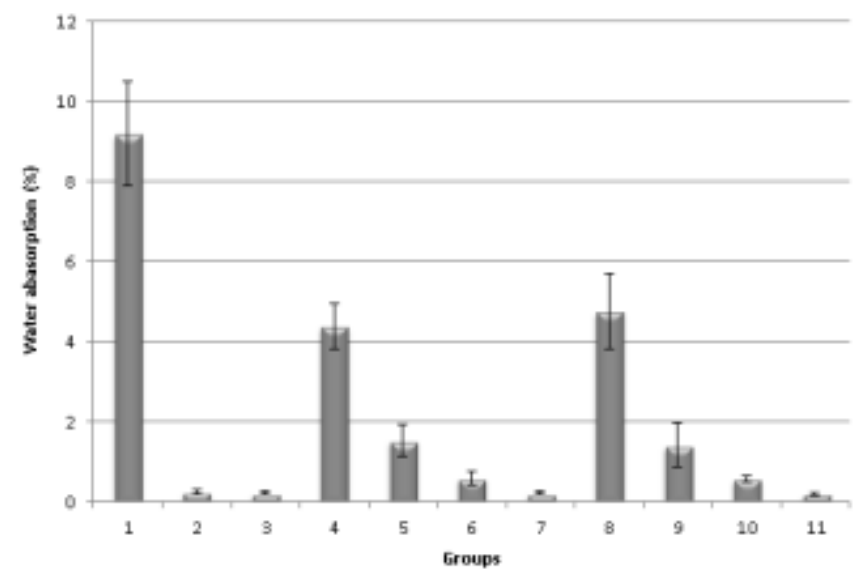

Figure 3: Water absorption data. 
It is verified that the standard deviation (SD) of the $\mathrm{AD}$ decreased with the increased of the sintering temperature of the specimens. Indicating relevant reliability of the results in higher sintering temperatures. The densities results in this study are close to those of Lu et al (2014) who found density values of 1.70 to $2.15 \mathrm{~g} / \mathrm{cm} 3$, with sintering temperature between 950 and $1100{ }^{\circ} \mathrm{C}$ [21] and forming pressure of $100 \mathrm{MPa}$, almost four times that used in this research. The same researchers found values of density between 1.70 and $2.00 \mathrm{~g} / \mathrm{cm} 3$ in another composition used [6].

Table 5 shows the linear contraction in the width of the specimens of all groups. The lowest values of linear contraction were found at the lowest sintering temperature. The addition of the cerium dioxide favored a lower contraction above the sintering temperature of $650{ }^{\circ} \mathrm{C}$. Above the sintering temperature of $670{ }^{\circ} \mathrm{C}$, the linear contraction has not a considerable increase, getting close to $14 \%$.

Table 5: Linear contraction of the width of specimens.

\begin{tabular}{l|l|l|l|l|l|l|l|l|l}
\hline \multicolumn{2}{l}{ LINEAR CONTRACTION $(\%)$} \\
\hline & & $650{ }^{\circ} \mathrm{C}$ & \multicolumn{2}{l|}{$675^{\circ} \mathrm{C}$} & \multicolumn{2}{l|}{$700{ }^{\circ} \mathrm{C}$} & \multicolumn{2}{l}{$750{ }^{\circ} \mathrm{C}$} \\
\hline & P / MPa & mean & SD & mean & SD & mean & SD & mean & SD \\
\hline $\mathrm{C} 1$ & 11.6 & 9.23 & 0.48 & - & - & 14.90 & 0.77 & 14.67 & 0.76 \\
\hline $\mathrm{C} 2$ & 25.8 & 10.40 & 0.54 & 13.94 & 0.72 & 14.08 & 0.73 & 14.33 & 0.74 \\
\hline $\mathrm{C} 3$ & 25.8 & 9.74 & 0.50 & 13.41 & 0.69 & 13.78 & 0.71 & 14.01 & 0.72 \\
\hline
\end{tabular}

The results of the three-point bending test of the groups tested are shown in Table 6. An increase in bending stress values with a sintering temperature of 650 to $700{ }^{\circ} \mathrm{C}$ is observed, however, with a reduction in the temperature of $750{ }^{\circ} \mathrm{C}$.

Table 6: Mean values of the flexural strength.

\begin{tabular}{l|l|l|l}
\hline & $\sigma o(\mathrm{MPa})$ & $\mathrm{m}$ & $\mathrm{R}^{2}$ \\
\hline G1 & 40.77 & 2.34 & 0.962 \\
\hline G2 & 60.00 & 6.43 & 0.936 \\
\hline G3 & 53.62 & 6.73 & 0.986 \\
\hline G4 & 40.57 & 2.87 & 0.971 \\
\hline G5 & 60.57 & 4.86 & 0.929 \\
\hline G6 & 66.89 & 8.91 & 0.940 \\
\hline G7 & 52.51 & 6.49 & 0.970 \\
\hline G8 & 40.50 & 3.23 & 0.958 \\
\hline G9 & 55.39 & 4.01 & 0.879 \\
\hline G10 & 60.55 & 6.22 & 0.944 \\
\hline G11 & 51.20 & 11.84 & 0.954
\end{tabular}

Figure 4 shows the variation of the flexural strength with the sintering temperature. It is verified that the average values of flexural strength of the specimens conformed with only glass powder were higher than those with addition of cerium dioxide. Thus, cerium dioxide reduced the values of fracture resistance at all temperatures. A rise in bending strength is observed with increasing sintering temperature and also with increasing forming load, except when the sintering temperature was $750{ }^{\circ} \mathrm{C}$. In addition, the standard deviation, $\mathrm{SD}$, of the flexural strength decreases with increasing sintering temperature, except at $700{ }^{\circ} \mathrm{C}$, with a forming pressure of $25.8 \mathrm{MPa}$ and with addition of cerium dioxide to the glass powder. At temperatures of 675 and $700{ }^{\circ} \mathrm{C}$, cerium dioxide reduced bending strength but enhanced by $750{ }^{\circ} \mathrm{C}$. During the sintering process the reduction of porosity occurs in favor of the increase of its density and its mechanical resistance. If the temperature is low, it may not be sufficient to complete the sintering and this justifies the lower flexural strength, such as lower densities and higher water absorption, indicating a higher porosity at lower sintering temperatures. Considering their respective values of standard deviation, it is seen that the optimum temperature tends to be near to $700{ }^{\circ} \mathrm{C}$ than $650{ }^{\circ} \mathrm{C}$. It is interesting to note that, for the specimens with only glass powder and conformed with higher pressure, the variation of $25^{\circ} \mathrm{C}$ between the first two temperatures analyzed (650-675 ${ }^{\circ} \mathrm{C}$ ) arose the increase in a further $50 \%$ in the rupture tension. 


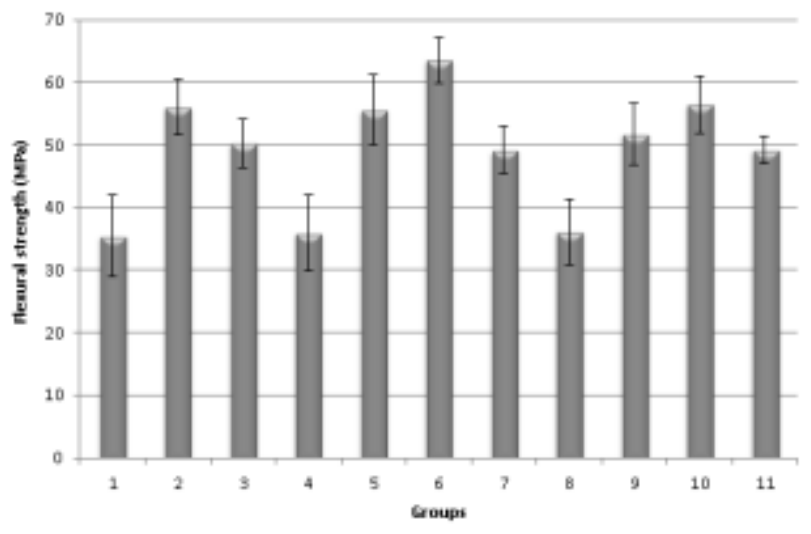

Figure 4: Flexural strength analysis for all groups.

Table 7 show some Weibull parameters for all the specimens produced. These results are important because it is indicative of the reliability of the results, in statistical terms, of the mechanical properties of the produced specimens. For the highest values of the standard deviation, SD, the lowest Weibull modulus (m) values are associated. Confirming that the most reliable results are those with the largest Weibull modulus and the smallest standard deviations. Thus, with increasing sintering temperature, there was an increase in the Weibull modulus and a decrease in the standard deviation, SD, of the flexural strength, except for the specimens with only glass powder, with a higher forming pressure, $25.8 \mathrm{MPa}$ and that were sintered at $750{ }^{\circ} \mathrm{C}$. In this case, there was a decrease in the Weibull modulus and a small increase in the standard deviation, SD (Tables 6 and 7).

Table 6 and Figure 4 show that among the 11 groups analyzed, G1 and G11 had the highest and lowest standard deviation, reaching values of approximately 13.15 and $4.30 \%$, respectively. The lowest standard deviation is associated with the largest Weibull modulus of 11.84; which occurred with higher sintering temperature, higher forming pressure and addition of cerium dioxide to the glass powder.

On the more specific analysis with respect to the Weibull modulus, as shown in Figure 5, the group 11 had its magnitude considerably increased, indicating that the addition of cerium dioxide in its composition, the increase of the forming pressure and the higher temperature of resulted in very reliable results. The lower sintering temperature, G1, G4 and G8 showed very low Weibull modulus, justifying the incomplete sintering of the specimens, which results in lower homogeneity of the specimens, with open pores in most of the specimens, which generates the lower specimen density.

Table 7: Weibull parameters.

\begin{tabular}{l|l|l|l|l}
\hline \multicolumn{5}{l}{ GLASS POWDER ONLY AND CONFORMED $11.6 \mathrm{MPa}$} \\
\hline Temperature $\left({ }^{\circ} \mathrm{C}\right)$ & $\sigma_{\mathrm{m}}(\mathrm{MPa})$ & $\sigma_{0}(\mathrm{MPa})$ & $\mathrm{m}$ & $\mathrm{R}^{2}$ \\
\hline $650(\mathrm{G} 1)$ & 35.49 & 40.77 & 2.34 & 0.962 \\
\hline $700(\mathrm{G} 2)$ & 56.05 & 60.00 & 6.43 & 0.936 \\
\hline $750(\mathrm{G} 3)$ & 50.25 & 53.62 & 6.73 & 0.986 \\
\hline GLASS POWDER ONLY AND CONFORMED $25.8 \mathrm{MPa}$ \\
\hline $650(\mathrm{G} 4)$ & 35.95 & 40.57 & 2.87 & 0.971 \\
\hline $675(\mathrm{G} 5)$ & 55.59 & 60.57 & 4.86 & 0.929 \\
\hline $700(\mathrm{G} 6)$ & 63.55 & 66.89 & 8.91 & 0.940 \\
\hline $750(\mathrm{G} 7)$ & 49.09 & 52.51 & 6.49 & 0.970 \\
\hline GLASS POWDER ONLY AND CONFORMED $25.8 \mathrm{MPa}$ \\
\hline $650(\mathrm{G} 8)$ & 36.12 & 40.50 & 3.23 & 0.958 \\
\hline $675(\mathrm{G} 9)$ & 51.78 & 55.39 & 4.01 & 0.879 \\
\hline $700(\mathrm{G} 10)$ & 56.46 & 60.55 & 6.22 & 0.944 \\
\hline $750(\mathrm{G} 11)$ & 49.21 & 51.20 & 11.84 & 0.954 \\
\hline
\end{tabular}


All the $\mathrm{R}^{2}$ correlation factors were close to or above 0.9 , and according to Defez et al, who use 0.75 as the lowest acceptable value of the correlation factor for Weibull's analysis [22], it was considered acceptable, all factors of all groups of studies. Figure 6 shows the comparative and qualitative analysis of the correlation factor for all groups.

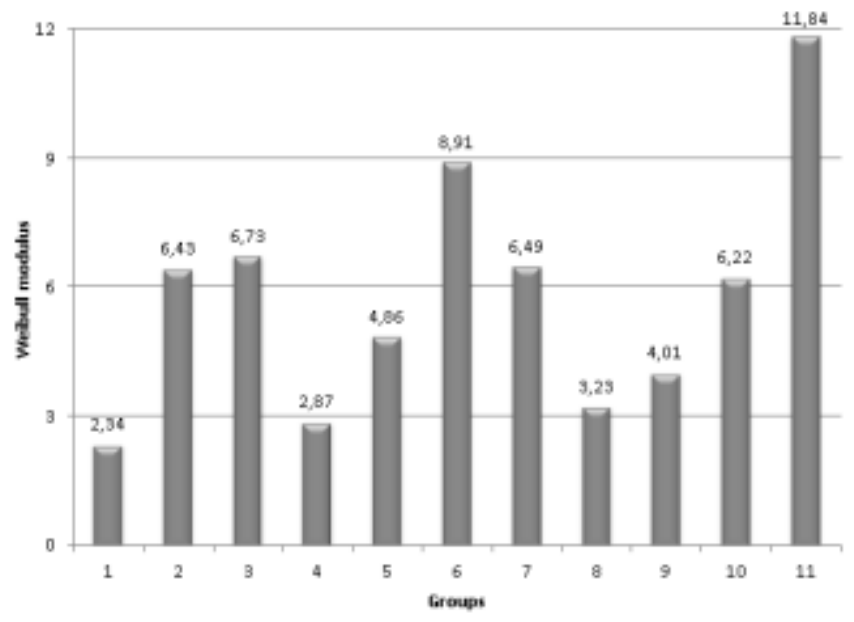

Figure 5: Analysis of the Weibull modulus for all groups.

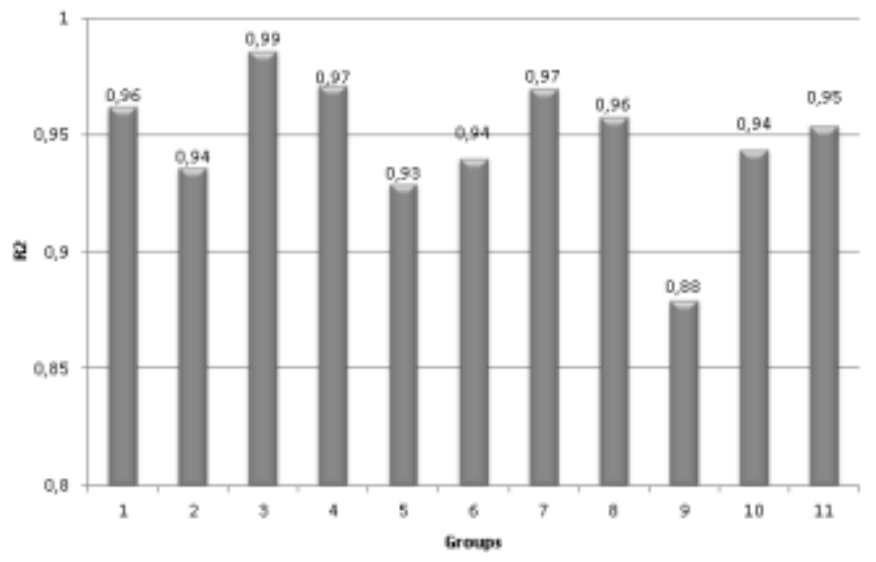

Figure 6: Correlation factor $\mathrm{R}^{2}$.

In Figure 7 are represented all the specimens of each group used to determine the Weibull modulus. The representation of each test body in the discretized form (points), it became possible to establish a trend curve around the points of each group. Due to the intense results in the Figure 7, it becomes necessary to analyze the groups separately. Thus, it is important to compare the groups at the same sintering temperature. Figure 8 shows all groups analyzed in the sintering temperature of $650{ }^{\circ} \mathrm{C}$. It can be observed that the results are quite distributed in the horizontal axis, that is, it indicates that there is a great dispersion in the values of $\mathrm{Ln} \sigma_{\mathrm{f}}$ for all sintered specimens at a temperature of $650^{\circ} \mathrm{C}$. 


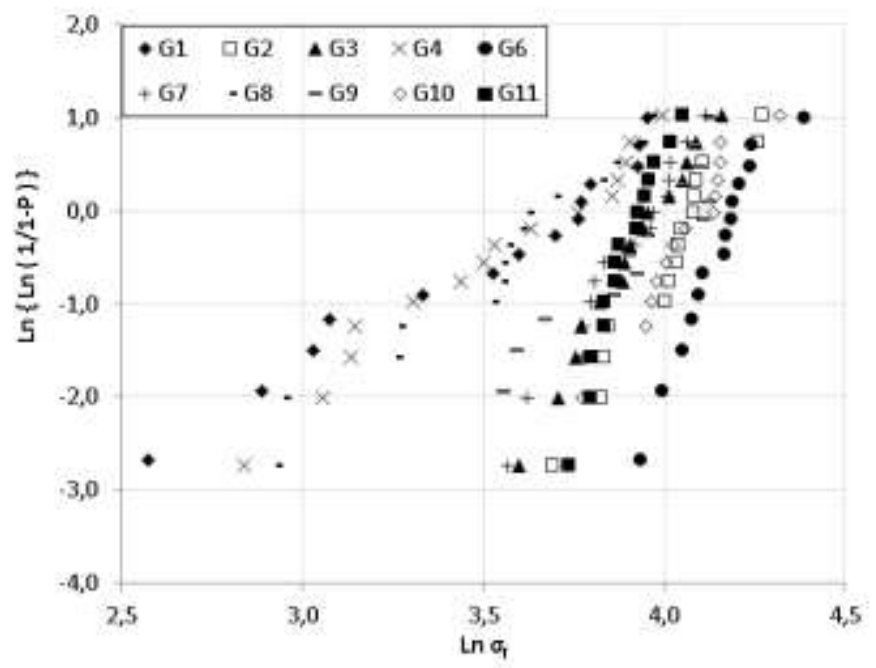

Figure 7: Weibull modulus of all groups.

Figure 9 shows that the slope of the line, trend curve, at the temperature of $700{ }^{\circ} \mathrm{C}$ is higher than at the sintering temperature of $650{ }^{\circ} \mathrm{C}$. This is due to the intermediate dispersion of $\mathrm{Ln} \sigma_{\mathrm{f}}$ in relation to the lower and upper temperature. Therefore, the results indicate more reliability, in statistical terms, and are related to the improvement of the mechanical properties of the groups at a temperature of $700{ }^{\circ} \mathrm{C}$.

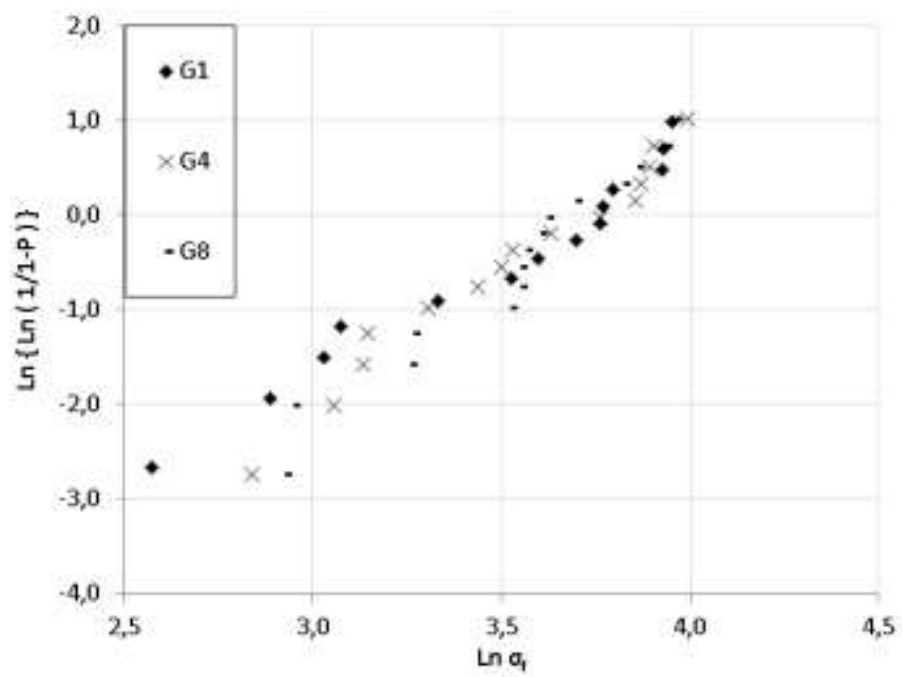

Figure 8: Weibull parameters for the sintering temperature of $650{ }^{\circ} \mathrm{C}$.

Figure 10 shows that the distribution of the Weibull modulus, for groups 3, 7 and 11; where the specimens were sintered at $750{ }^{\circ} \mathrm{C}$, presented lower dispersions of $\mathrm{Ln} \sigma_{\mathrm{f}}$ in relation to the lower temperatures. Significant dependence of the Weibull modulus on temperature is noticeable, that is, there was a increase in slope of the trend lines, i.e., Weibull's modulus, in the temperature of $750{ }^{\circ} \mathrm{C}$. Thus, the higher sintering temperature showed more reliable results.

In order to confirm the composition of the crystalline phases precipitating in the glasses, the XRD patterns of the glasses after the heat treatment were measured using an X-ray diffraction analyzer. Figure 11 shows that at the lower forming pressure, 11.6 MPa, the structure remains amorphous at lower sintering temperatures, forming some crystalline structure only at $750{ }^{\circ} \mathrm{C}$. When the forming pressure increased, at the lower sintering temperature, crystalline phase formation, quartz, occurred, Figure 12. It can be seen in Figure 13 that the addition of cerium dioxide did not favor the formation of other crystalline structures. 


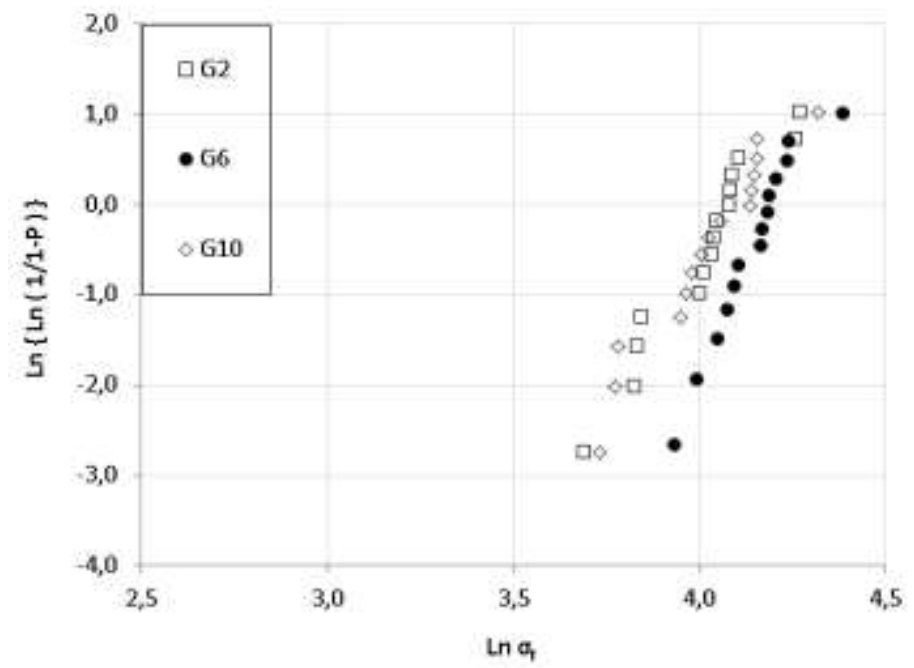

Figure 9: Weibull parameters for the sintering temperature of $700{ }^{\circ} \mathrm{C}$.

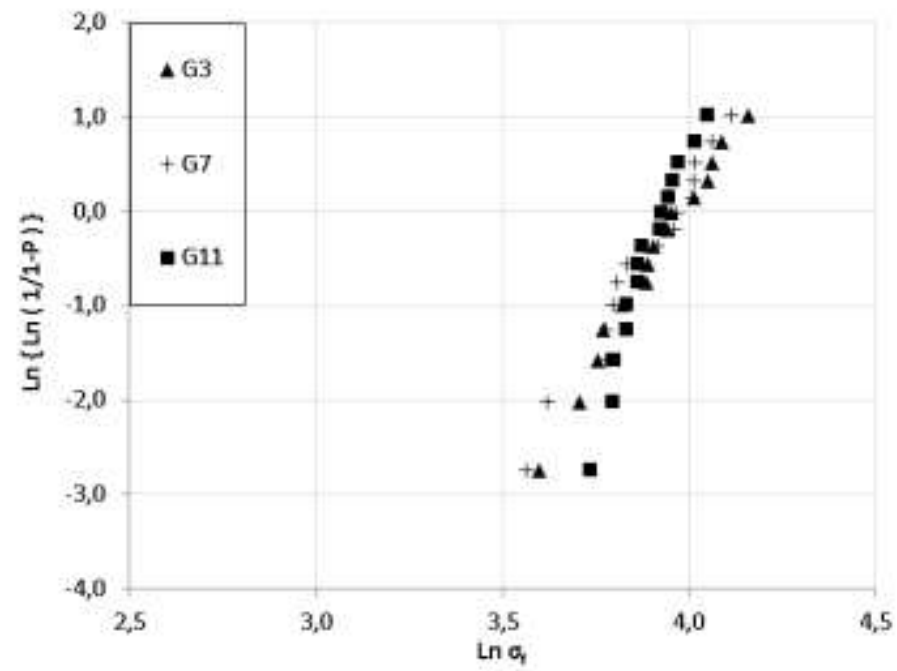

Figure 10: Weibull parameters for the sintering temperature of $750{ }^{\circ} \mathrm{C}$.

The flexural strength values found in the literature for glass ceramics are dependent on the compositions of the specimens, the type and the forming pressure, such as temperature and sintering time. There is a great diversity of flexural strength values. Zhao et al (2012) used furnace slag mixed with silicon oxide and calcium fluoride. The sintering temperature varied from 780 to $960^{\circ} \mathrm{C}$ and the flexural strength ranged from 13.0 to $45.8 \mathrm{MPa}$ [23]. These values are similar to the values found in this research. Lu et al (2016) found a maximum density of $1.94 \mathrm{~g} / \mathrm{cm}^{3}$, with the sintered specimens at the temperature of $1000{ }^{\circ} \mathrm{C}$ and with addition of magnesium oxide. The flexural strength varied between 66 and $84 \mathrm{MPa}$ [6]. The values of the densities of this project were higher in all conditions than the density of Lu and collaborators, though, the average of the flexural strength were smaller. 


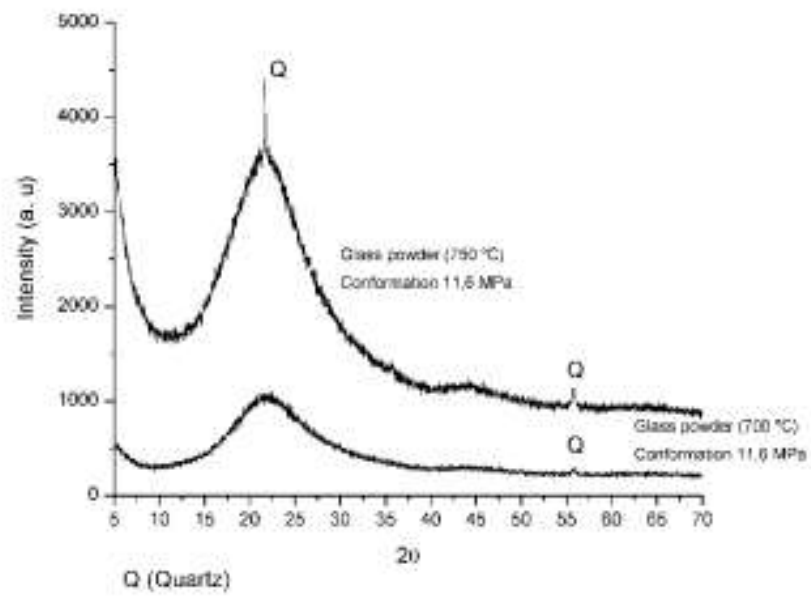

Figure 11: X-ray diffraction of the specimens with only glass powder, conformed at the lowest pressure, 11.6 MPa and sintered at temperatures of 700 and $750{ }^{\circ} \mathrm{C}$.

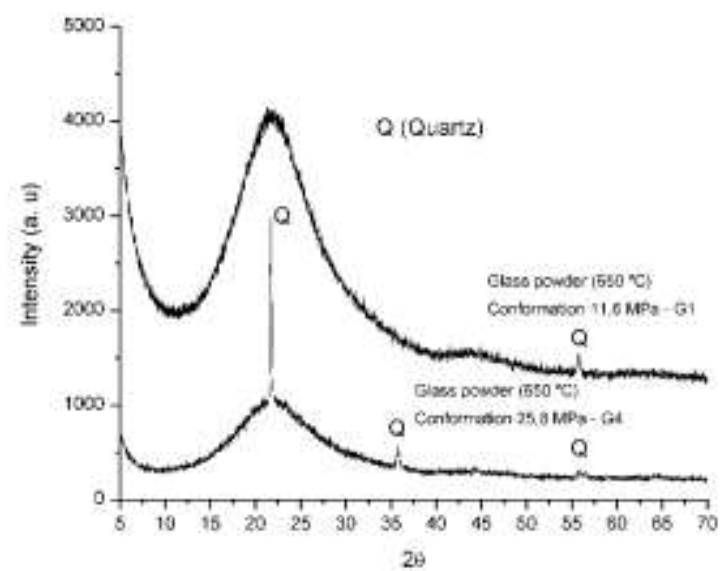

Figure 12: X-ray diffraction of the specimens with only glass powder, sintered at a temperature of $650{ }^{\circ} \mathrm{C}$ and conformed to 11.6 and $25.8 \mathrm{MPa}$.

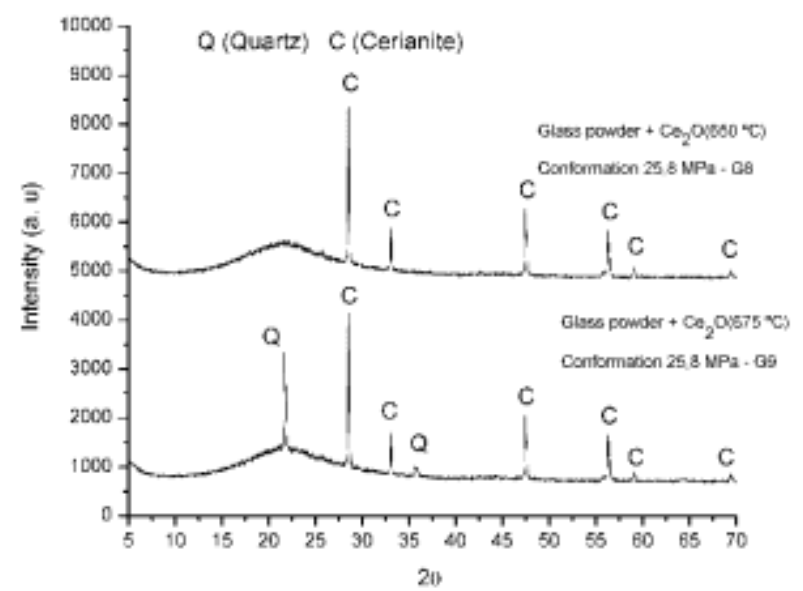

Figure 13: X-ray diffraction of the specimens with $\mathrm{CeO}_{2}$ and glass powder, formed at a pressure of $25.8 \mathrm{MPa}$, sintered at a temperature of 650 and $675^{\circ} \mathrm{C}$. 


\section{CONCLUSIONS}

The best mechanical properties were with the specimens sintered at $700{ }^{\circ} \mathrm{C}$. At the higher conformation pressure, 25.8 MPa, the flexural strength increased from approximately 56 to $64 \mathrm{MPa}$, at the sintering temperature of $700{ }^{\circ} \mathrm{C}$. In the temperature of $650{ }^{\circ} \mathrm{C}$, the highest conformation pressure, $25.8 \mathrm{MPa}$; presented crystalline structure of quartz, with defined well peaks. While at the lowest pressure, of $11.6 \mathrm{MPa}$, the diffractogram was typical of amorphous material.

The addition of cerium dioxide did not improve the resistance to flexural strength of the glass ceramics, but increased the reliability of the results, showing modulus of Weibull, $\mathrm{m}$, higher at the sintering temperature of $650 \mathrm{C}$ and arriving in, $\mathrm{m}=11.8$; in the temperature of $750 \mathrm{C}$.

It was also found that the cerium dioxide did not react with the glass powder, maintaining its crystalline structure, Cerianite.

\section{ACKNOWLEDGMENT}

The authors would like to thank the Instituto Nacional de Tecnologia (INT), Conselho Nacional de Desenvolvimento Científico e Tecnológico (CNPq), Coordenação de Aperfeiçoamento de Pessoal de Nível Superior (CAPES) and Fundação de Amparo à Pesquisa do Estado do Rio de Janeiro (FAPERJ) for their support.

\section{BIBLIOGRAFIA}

[1] FENG, D., ZHU, Y., et al.., "Influence investigation of CaF2 on the LAS based glass-ceramics and the glass-ceramic/diamond composites", Journal of the European Ceramic Society, v. 36, n. 10, pp. 2579-2585, Aug., 2016.

[2] MOLLA, A.R., TARAFDER, A., et al., "Fabrication and properties of Nd3+-doped ferroelectric barium bismuth titanate glass-ceramic nanocomposites", Journal of Alloys and Compounds, v. 680, pp. 237-246, Sep., 2016.

[3] CAO, J., DONG X., et al., "Recycling of waste fly ash for production of porous mullite ceramic membrane supports with increased porosity", Journal of the European Ceramic Society, v. 34, n. 13, pp. 31813194, Nov., 2014.

[4] ANDREOLA, F., BARBIERI, L., et al., "Recycling of industrial wastes in ceramic manufacturing: State of art and glass case studies", Ceramics International, v. 42, n. 12 pp. 13333-13338, September, 2016.

[5] CAO, J., LU, J.B., et al., "Sinterability, Microstructure and compressive strength of porous glass ceramics from metallurgical silicon slag and waste glass", Ceramics International, v. 42, n. 8, pp. 10079-10084, Jun., 2016.

[6] LU, J., CONG, X., LU, Z., "Influence of magnesia on sinter-crystallization, phase composition and flexural strength of sintered glass-ceramics from waste materials", Materials Chemistry and Physics, v. 174, pp. 143-149, May, 2016.

[7] WANG, X., WU, L., et al., "Preparation and characterization of SO3-doped barium borosilicate glass ceramics containing zirconolite and barite phases", Ceramics International, v. 43, n. 1, pp. 534-539, Jan., 2016.

[8] LIU, J., MENG, J., et al., "Effect of rare earth Ce on the far infrared radiation property of iron ore tailings ceramics", Materials Research Bulletin, v. 66, pp. 26-31, Jun., 2015.

[9] LOPES, R.S., TRINDADE, V.A., et al., "Cinética da cristalização de pó de vidro reciclado de para-brisa para produção de vitrocerâmica", In: XVI Encontro de Modelagem Computacional IV Encontro de Ciência e Tecnologia de Materiais, Ilhéus, Oct., 2013.

[10] ZHANG, Q., HE, F., et al., "Preparation of high strength glass ceramic foams from waste cathode ray tube and germanium tailings", Construction and Building Materials, v. 111, pp. 105-110, May, 2016.

[11] GUNDUZ, O. et al., "Preparation and evaluation of cerium oxide-bovine hydroxyapatite composites for biomedical engineering applications", journal of the mechanical behavior of biomedical materials, v. 35, pp. 70-76, Apr., 2014.

[12] AMERICAN SOCIETY FOR TESTING AND MATERIALS C1161 - 13: Standard Test Method for Flexural Strength of Advanced Ceramics at Ambient Temperature, BarrHarbor, 2014. 
[13] FARAHANI, F., GHOLAMIPOUR, R., "Statistical Weibull analysis of compressive fracture strength of (Zr55Cu30Al10Ni5)99Nb1 bulk metallic glass", Journal of Alloys and Compounds, v. 695, pp. 2740-2744, Feb., 2017.

[14] MERKUS, H. G. Particle size measurements: fundamentals, practice, quality. Springer Science \& Business Media, 2009.

[15] PARTYKA, J., LÉSNIAK, M., "Raman and infrared spectroscopy study on structure and microstructure of glass-ceramic materials from $\mathrm{SiO} 2-\mathrm{Al} 2 \mathrm{O} 3-\mathrm{Na} 2 \mathrm{O}-\mathrm{K} 2 \mathrm{O}-\mathrm{CaO}$ system modified by variable molar ratio of SiO2/A12O3", Spectrochimica Acta Part A: Molecular and Biomolecular Spectroscopy, v. 152, pp. 82-91, Jan., 2016.

[16] MERKUS, H. G., "Particle size measurements: fundamentals, practice, quality", Springer Science \& Business Media, 2009.

[17] CARTER, C. B., NORTON, M. G., “Ceramic materials science and engineering”, 2.ed, New York: Springer Science+Business Media. 2013.

[18] FREDERICCI, C., YOSHIMURA, H.N., et al., "Effect of temperature and heating rate on the sintering of leucite-based dental porcelains", Ceramics International, v. 37, n. 3, pp. 1073-1078, Apr., 2011.

[19] FAN, C.S., LI, K.C., "Production of insulating glass ceramics from thin film transistor-liquid crystal display (TFT-LCD) waste glass and calcium fluoride sludge", Journal of cleaner production, v. 57, pp. 335341, May, 2013.

[20] ZHANG, W., LIU, H., "A low cost route for fabrication of wollastonite glass-ceramics directly using soda-lime waste glass by reactive crystallization-sintering", Ceramics International, v. 39, n. 2, p. 1943-1949, Aug., 2013.

[21] LU, J., LU, Z., et al. "Influence of particle size on sinterability, crystallisation kinetics and flexural strength of wollastonite glass-ceramics from waste glass and fly ash", Materials Chemistry and Physics, v. 148, n. 1-2, pp.449-456, Nov., 2014.

[22] DEFEZ, B., PERIS-FAJARNÉS, G., et al. "Influence of the load application rate and the statistical model for brittle failure on the bending strength of extruded ceramic tiles", Ceramics International, v. 39, n. 3, pp. 3329-3335, Apr., 2013.

[23] ZHAO, Y., CHEN, D., et al. "Preparation of low cost glass-ceramics from molten blast furnace slag", Ceramics International, v. 38, n. 3, pp. 2495-2500, Apr., 2012.

\section{ORCID}

Hiasmim Rohem Gualberto

Enzo Hanning

Luiz Carlos Bertolino

Karla Mayara Arguelles Simões

Mônica Calixto de Andrade

Edgard Poiate Júnior https://orcid.org/0000-0003-2807-6149

https://orcid.org/0000-0002-6467-1749

https://orcid.org/0000-0002-0908-180X

https://orcid.org/0000-0002-4144-9029

https://orcid.org/0000-0001-6530-0651

https://orcid.org/0000-0001-8937-4428 